\title{
HUBUNGAN PERILAKU PERAWAT DENGAN KELENGKAPAN PENDOKUMENTASIAN ASUHAN KEPERAWATAN DI RUMAH SAKIT
}

\author{
Muhaini Atmayana Purba / 181101131 \\ $\underline{\text { muhainipurba21@gmail.com }}$
}

\begin{abstract}
ABSTRAK
Latar belakang : Pelaksanaan pendokumentasian rekam medis dilaksanakan oleh berbagai profesi tenaga kesehatan salah satunya adalah perawat. Berdasarkan studi pendahuluan dengan sampel 10 dokumen rekam medis ruang bedah tahun 2013 yang diambil secara acak hanya $40 \%$ yang diisi secara lengkap dan $60 \%$ tidak lengkap. Tujuan : Tujuan penulisan ini yaitu mengidenifikasi hubungan perilaku perawat dengan kelengkapan pendokumentasian asuhan keperawatan di rumah sakit. Metode : Metode yang digunakan merupakan literatur review atau suatu perbandingan atau analisis antara satu jurnal dengan jurnal lainnya dari berbagai sumber seperti referensi jurnal, buku teks dan e-book. Hasil : Hasil penelitian menunjukkan bahwa 35,55\% memiliki pengetahuan baik 33,33\% memiliki pengetahuan cukup dan 31,11\% memiliki pengetahuan kurang. Kelengkapan pengisian dokumentasi asuhan keperawatan ruang bedah sebanyak 29,5\% sedangkan ketidaklengkapannya sebanyak 70,5\%. Kesimpulan : Berdasarkan hasil uji statistik didapatkan bahwa ada hubungan antara pengetahuan perawat dengan kelengkapan pengisian dokumentasi asuhan keperawatan dengan hasil $\mathrm{P}=0,001(\mathrm{P}<0,05)$. Saran dalam penelitian ini adalah perlu dilakukan pelatihan, pendidikan, dan sosialisasi mengenai hal tersebut.
\end{abstract}

Kata Kunci : Perilaku perawat, kelengkapan pendokumentasian, asuhan keperawatan.

\begin{abstract}
Background : The implementation of medical record documentation is carried out by various health professionals, one of which is a nurse. Based on a preliminary study with a sample of 10 operating room medical record documents in 2013 taken at random only $40 \%$ were filled in completely and $60 \%$ were incomplete. Purpose : The purpose of this paper is to identify the relationship of nurses' behavior with the completeness of nursing care documentation in the hospital. Method : The method used is a literature review or a comparison or analysis of one journal with other journals from various sources such as journal references, textbooks and ebooks. Results : The results showed that $35.55 \%$ had good knowledge $33.33 \%$ had sufficient knowledge and $31.11 \%$ had less knowledge. The completeness of filling the surgical theater nursing care documentation was $29.5 \%$ while the incompleteness was $70.5 \%$. Conclusion : Based on the results of statistical tests found that there is a relationship between nurses' knowledge with the completeness of filling nursing care documentation with the results of $\mathrm{P}=$ $0.001(\mathrm{P}<0.05)$. The suggestion in this research is that training, education and outreach are needed.
\end{abstract}

Keywords : Nurse behavior, completeness of documentation, nursing care. 


\section{Latar Belakang}

Rekam medis dikatakan lengkap jika terisinya data identifikasi pasien, pelaporan penting, otentikasi serta menggunakan tata cara pendokumentasian yang baik (Hatta, 2008). Apabila pengisian rekam medis tidak lengkap maka akan mengakibatkan informasi yang ada dalam rekam medis menjadi tidak tepat, tidak akurat, dan tidak sah atau legal. Selain itu, ketidaklengkapan pengisian dokumen rekam medis dapat mempengaruhi terhadap kegunaan rekam medis seperti administrasi, hukum, keuangan, penelitian, pendidikan dan dokumentasi.

Faktor-faktor yang berpengaruh dalam pelaksanaan pendokumentasian adalah pengetahuan, usia dan motivasi (Setiyarini, 2004). Wawan dan Dewi (2011) mendeskripsikan bahwa pengetahuan merupakan hasil "tahu" dan ini terjadi setelah orang mengadakan penginderaan terhadap suatu objek tertentu. Pengetahuan pelaksanaan pendokumentasian harus dimiliki oleh berbagai profesi tenaga kesehatan salah satunya adalah perawat. Seorang perawat mempunyai peran dalam melaksanakan pendokumentasian asuhan keperawatan dalam rekam medis (Damayanti, 2013).

Seorang perawat harus mampu melaksanakan dokumentasi asuhan keperawatan dalam rekam medis dengan lengkap, jelas, akurat dan dapat dipahami oleh orang lain. Namun, dalam pelaksanaannya pengisian dokumentasi asuhan keperawatan dalam rekam medis oleh tenaga perawat pada dasarnya masih memiliki permasalahan, yaitu masih rendahnya tingkat pemahaman terhadap pendokumentasian asuhan keperawatan. Hal ini sesuai dengan hasil penelitian Mastini (2013) tentang hubungan pengetahuan, sikap dan beban kerja dengan kelengkapan pendokumentasian asuhan keperawatan irna di RSUP Sanglah Denpasar diperolehnya responden dengan pengetahuan kurang dengan kelengkapan pendokumentasian tidak sesuai sebanyak $86,4 \%$. Mengingat pentingnya rekam medis untuk rumah sakit, maka perlu adanya pengendalian terhadap pengisian rekam medis yang dilakukan secara berkala untuk menjaga kualitas isi rekam medis sehingga informasi yang dihasilkan menjadi lebih lengkap, jelas dan akurat serta berkesinambungan. Mahyunita (2012) menyatakan bahwa rekam medis 
yang lengkap dapat memenuhi standar untuk mendapatkan predikat akreditasi. Selain itu, rekam medis yang lengkap dapat dijadikan sebagai perlindungan hukum bagi pasien, rumah sakit maupun dokter dan tenaga kesehatan lainnya, sebagai dasar dalam perhitungan biaya pembayaran pelayanan medis, alat komunikasi antara dokter dan tenaga kesehatan lainnya yang ikut andil dalam proses pemberian pelayanan serta dapat dijadikan sebagai bahan yang berguna untuk analisa, penelitian dan evaluasi terhadap kualitas pelayanan yang telah diberikan kepada pasien. Data diatas didukung oleh survei pendahuluan yang dilakukan di RSUD dr.Soekardjo pada tanggal 10 Februari 2014. Peneliti memperoleh data dari bagian seksi rekam medis pada bagian analizing, diketahui presentase ketidaklengkapan dokumentasi asuhan keperawatan yang tertinggi terdapat di ruang bedah.

\section{Tujuan}

Tujuan penulisan ini yaitu mengidenifikasi hubungan perilaku perawat dengan kelengkapan pendokumentasian asuhan keperawatan di rumah sakit.

\section{Metode}

Metode yang digunakan merupakan literatur review atau suatu perbandingan atau analisis antara satu jurnal dengan jurnal lainnya dari berbagai sumber seperti referensi jurnal, buku teks dan e-book.

\section{Hasil \& Pembahasan}

$$
\text { Menurut Ardika }
$$

kelengkapan pendokumentasian asuhan keperawatan dipengaruhi oleh berbagai macam faktor seperti latar belakang pendidikan, lama masa kerja, pengetahuan, keterampilan, motivasi dan psikologis. Hal tersebut didukung oleh pernyataan Setiyarini (2004) dalam penelitiannya yang mengemukakan bahwa salah satu faktor yang berpengaruh terhadap pelaksanaan pendokumentasian adalah pengetahuan.

$$
\text { Pengetahuan perawat }
$$
menentukan tindakan perawat dalam memberikan pelayanan kepada pasien, sehingga tindakan perawat yang dilandasi oleh

pengetahuan akan memberikan pelayanan yang lebih baik dibandingkan dengan perawat yang melakukan

tindakannya tanpa didasari oleh pengetahuan. Pengetahuan perawat juga sangat terpengaruh terhadap kelengkapan pengisian dokumentasi asuhan keperawatan. Hasil penelitian menunjukkan bahwa pengetahuan perawat ruang bedah RSUD 
dr.Soekardjo Kota Tasikmalaya hampir setengahnya memiliki pengetahuan yang baik yaitu berjumlah 16 perawat.

Pengetahuan perawat sangat berpengaruh terhadap kelengkapan pengisian dokumentasi asuhan keperawatan. Hal ini sesuai dengan hasil penelitian diketahui bahwa dari 271 dokumen yang menjadi sampel sebagian besar dokumentasi asuhan keperawatan ruang bedah periode triwulan I di RSUD dr.Soekardjo Kota Tasikmalaya diisi secara tidak lengkap. Seorang perawat harus mengisi dokumentasi asuhan keperawatan secara lengkap dan jelas setelah pasien menerima pelayanan. Hal ini sesuai dengan Permenkes No: 269/MENKES/PER/III/2008 pasal 2 ayat 1 yang menyebutkan bahwa rekam medis harus dibuat secara lengkap dan jelas. Rekam medis yang lengkap memuat informasi yang berkesinambungan, sehingga dengan adanya kesinambungan informasi tersebut maka setiap pasien yang datang berobat, dokter dan petugas kesehatan lainnya akan memperoleh informasi yang lengkap tentang riwayat penyakit terdahulu secara komprehensif (Shofari, 2002). Selain itu, dokumentasi asuhan keperawatan mempunyai banyak manfaat dilihat dari berbagai aspek seperti aspek hukum, kualitas pelayanan, komunikasi, keuangan, pendidikan, penelitian dan akreditasi. Rekam medis yang tidak lengkap akan berdampak terhadap kegunaan rekam medis seperti administrasi, legal, keuangan, pendidikan, penelitian dan

dokumentasi. Selain itu, etidaklengkapan rekam medis akan menghasilkan informasi yang tidak tepat dan bersifat legal. Maka dari itu, setiap tenaga kesehatan yang memberikan pelayanan terhadap pasien harus mengisi rekam medis secara lengkap untuk menghindari hal-hal yang tidak diinginkan.

$$
\text { Notoatmodjo }
$$

mengemukakan bahwa pengetahuan merupakan faktor yang sangat penting untuk menentukan tindakan seseorang, sehingga perilaku yang didasari pengetahuan akan lebih

bertahan lama dibandingkan yang tidak didasari oleh pengetahuan, artinya semakin tinggi pengetahuan seseorang diharapkan semakin baik pula perilaku yang ditunjukannya.

Hal ini terbukti dari hasil penelitian bahwa perawat yang memiliki pengetahuan baik lebih banyak mengisi formulir dokumentasi 
asuhan keperawatan secara lengkap yaitu berjumlah 35 dokumen dibandingkan dengan perawat yang memiliki pengetahuan cukup berjumlah 33 dokumen dan perawat yang memiliki pengetahuan yang kurang mengisi dokumentasi asuhan keperawatan berjumlah 12 dokumen. Sedangkan perawat dengan kriteria pengetahuan baik mempunyai nilai ketidaklengkapan 62 dokumen, perawat dengan kriteria pengetahuan yang cukup mempunyai nilai ketidaklengkapan sebanyak 57 dokumen serta perawat yang memiliki kriteria pengetahuan yang kurang mempunyai nilai ketidaklengkapan sebanyak 72 dokumen. Dapat disimpulkan dari data tersebut bahwa perawat yang memiliki pengetahuan yang kurang cenderung mempunyai nilai ketidaklengkapan yang tinggi.

Berdasarkan hasil penelitian yang telah dilakukan uji statistik $C h i$ square, diketahui bahwa terdapat hubungan pengetahuan perawat dengan kelengkapan pengisian dokumentasi asuhan keperawatan. Ini sesuai dengan penelitian sebelumnya yang dilakukan oleh Ardika (2012) diRSUP Dr. Kariadi Semarang dan penelitian Pribadi (2009) di RSUD Kelet Provinsi Jawa Tengah Jepara yaitu adanya hubungan tingkat pengetahuan perawat dengan kelenkapan pengisian dokumentasi asuhan keperawatan.

\section{Kesimpulan \& Saran}

Pengetahuan perawat ruang bedah di RSUD dr.Soekardjo Kota Tasikmalaya adalah dari 45 perawat yang memiliki pengetahuan baik berjumlah 16 orang $(35,55 \%)$. Berbeda sedikit dengan perawat yang memiliki tingkat pengetahuan cukup berjumlah 15 orang $(33,33 \%)$ dan perawat yang memiliki pengetahuan kurang berjumlah 14 orang $(31,11 \%)$.

$$
\text { Kelengkapan pengisian }
$$

dokumentasi asuhan keperawatan ruang bedah periode triwulan I tahun 2013 adalah dari 271 dokumen yang dijadikan sampel oleh peneliti didapatkan kelengkapan pengisian dokumentasi asuhan keperawatan ruang bedah mencapai 80 dokumen $(29,5 \%)$, sedangkan ketidaklengkapan pengisian dokumentasi asuhan keperawatan ruang bedah yaitu 191 dokumen (70,5\%).

Dari hasil uji hubungan antara pengetahuan perawat dengan kelengkapan pengisian dokumentasi asuhan keperawatan diketahui bahwa adanya hubungan pengetahuan perawat 
dengan kelengkapan pengisian

dokumentasi asuhan keperawatan

dengan nilai $\mathrm{P}=0,001(\mathrm{P}<$

$0,05)$.

\section{Daftar Pustaka}

Ardika, R.G. (2012). Hubungan Antara Pengetahuan Perawat Tentang Rekam Medis Dengan Kelengkapan Pengisian Catatan Keperawatan. Semarang: Fakultas Kedokteran UNDIP

Arikunto, S. (2006). Prosedur Penelitian Suatu Pendekatan Praktik. Jakarta: Rineka Cipta

Arikunto, S. (2009). Prosedur Penelitian Suatu Pendekatan Praktik Revisi VI. Jakarta: Rineka Cipta

Arikunto, S. (2010). Prosedur Penelitian Suatu Pendekatan Praktik. Jakarta: Rineka Cipta

Depkes, RI. (2006). Pedoman Penyelenggaraan dan Prosedur Rekam Medis Rumah Sakit di Indonesia Revisi II. Jakarta: Direktorat Jenderal Bina Pelayanan Medik

Kemenkes Kesehatan Republik Indonesia. (2011). Pedoman Penyelenggaraan Rekam Medis di Indonesia. Jakarta : KEMENKES
Mastini, I G. A. A. P. (2013). Hubungan Pengetahuan, Sikap dan Beban Kerja Dengan Kelengkapan Pendokumentasian Asuhan Keperawatan Irna di RSUP Sanglah. Denpasar: Fakultas Ilmu Kesehatan Masyarakat Universitas Udayana

Notoatmodjo, S. (2005). Metodologi Penelitian Kesehatan. Jakarta: Rineka Cipta

Notoatmodjo, S. (2007). Kesehatan Masyarakat : Ilmu dan Seni.. Jakarta: Rineka Cipta

Notoatmodjo, S. (2010). Kesehatan Masyarakat : Ilmu dan Seni.. Jakarta: Rineka Cipta

Notoatmodjo, S. (2012). Metodologi Penelitian Kesehatan. Jakarta: Rineka Cipta

PermenkesNo.269/MENKES/PER/III/2 008 Tentang Penyelenggaraan Rekam Medis.Nursalam. (2002). Manajemen Keperawatan Aplikasi dalam Praktik Keperawatan Profesional. Penerbit Salemba Medika. Cetakan Pertama, Jakarta.

Rahmat, Ibrahim, dkk. (2012). Evaluasi Pelaksanaan Sistem Pemberian Asuhan Keperawatan di Ruang Rawat Inap Terhadap Kinerja 
Perawat. Berita Kedokteran

Masyarakat, Vol 28 No 1.

Simamora, R. H. (2008). Peran Manajer

Perawat Dalam Pembinaan Etika

Perawat Pelaksana Dalam

Peningkatan Kualitas Asuhan

Keperawatan. IKESMA

Simamora, R. H. (2009). Dokumentasi

Proses Keperawatan. Jember.

University Press

Simamora, R. H. (2010). Komunikasi

Dalam Keperawatan. Jember:

University Press

Sugiyono. (2008). Statistika Untuk

Penelitian. Bandung : CV

Alfabeta

Undang-Undang Republik Indonesia

Nomor 36 Tahun 2009 Tentang

Kesehatan

Undang-Undang Nomor 29 Tahun 2004

Tentang Praktik Kedokteran

Wawan, A dan M. Dewi. (2011). Teori

dan Pengukuran Pengetahuan,

Sikap, Dan Perilaku Manusia.

Yogyakarta: Nuha Medika Zaidin, A. H. (2009). Dasar-dasar Dokumentasi

Keperawatan. Jakarta : EGC 